\title{
Monuments and the Politics of Memory: Commemorating Kurt Eisner and the Bavarian Revolutions of 1918-1919 in Postwar Munich
}

Gavriel D. Rosenfeld

grosenfeld@fairfield.edu

Follow this and additional works at: https://digitalcommons.fairfield.edu/history-facultypubs Copyright 1997 Cambridge University Press

\section{Peer Reviewed}

\section{Repository Citation}

Rosenfeld, Gavriel D., "Monuments and the Politics of Memory: Commemorating Kurt Eisner and the Bavarian Revolutions of 1918-1919 in Postwar Munich" (1997). History Faculty Publications. 56.

https://digitalcommons.fairfield.edu/history-facultypubs/56

\section{Published Citation}

Rosenfeld, G. (1997) "Monuments and the Politics of Memory: Commemorating Kurt Eisner and the Bavarian Revolutions of 1918-1919 in Postwar Munich," Central European History, Volume 30, Nr. 2, 1997, pp. $221-251$.

This item has been accepted for inclusion in DigitalCommons@Fairfield by an authorized administrator of DigitalCommons@Fairfield. It is brought to you by DigitalCommons@Fairfield with permission from the rightsholder(s) and is protected by copyright and/or related rights. You are free to use this item in any way that is permitted by the copyright and related rights legislation that applies to your use. For other uses, you need to obtain permission from the rights-holder(s) directly, unless additional rights are indicated by a Creative Commons license in the record and/or on the work itself. For more information, please contact digitalcommons@fairfield.edu. 


\title{
Monuments and the Politics of Memory: Commemorating Kurt Eisner and the Bavarian Revolutions of 1918-1919 in Postwar Munich
}

\author{
Gavriel D. Rosenfeld
}

$\mathrm{G}$

IVEN the turbulent nature of recent German history, studies of postwar German memory understandably have focused upon the issue of Vergangenheitsbewältigung - the difficult process of "coming to terms" with the historical experience of the Third Reich and the Second World War. This topic's magnitude has rightly inspired considerable scholarly attention but, at the same time, it has also had the unintended effect of overshadowing other German struggles with memory. ${ }^{1}$ In recent years, however, this state of affairs has begun to change. As the epochal events of 1989-90 have forced Germans to confront still another burdensome historical legacy - that of communism-the increasing calls for a "second" Vergangenheitsbewältigung have, for better or worse, broken the monopolistic hold of the Third Reich on the nation's historical consciousness. ${ }^{2}$ Historians have already begun to speculate about the likely

1. Indeed, as some observers have pointed out, this is implicit in the very composition of the term Vergangenheitsbewaltigung itself. Its meaning, roughly "coming to terms with the past," has reduced an expansive term-the past-to but twelve years of German history. See Bernd Hey, "Die NS-Prozesse-Versuch einer juristischen Vergangenheitsbewältigung," Geschichte in Wissenschaft und Unterricht 6 (1981): 331. Most recent studies have been conservative critiques of the concept. See Manfred Kittel, Die Legende von der zweiten Schuld: Vergangenheitsbewältigung in der Ära Adenauer (Berlin, 1993); Michael Wolffsohn, Keine Angst vor Deutschland! (Erlangen, 1990), 96-110; Eckhard Jesse, “'Vergangenheitsbewältigung' in der Bundesrepublik Deutschland," Der Staat 26, no. 4 (1987): 539-65. See also, Peter Graf Kielmansegg, Lange Schatten: Vom Umgang der Deutschen mit der nationalsozialistischen Vergangenheit (Berlin, 1989) and Ulrich Brochhagen, Nach Nümberg: Vergangenheitsbewältigung und Westintegration in der Ära Adenauer (Hamburg, 1994).

2. Conservatives have taken up the call for the second Vergangenheitsbewältigung. See Karlheinz Weissmann, Rückruf in die Geschichte (Berlin, 1992). Christa Hoffmann, Stunden Null? Vergangenheitsbewältigung in Deutschland, 1945 und 1989 (Bonn, 1992). Martin Jay's "Once More an Inability to Mourn? Reflections on the Left Melancholy of Our Time," German Politics and Society 27 (Fall 1992), offers a view from a different perspective. 


\section{MONUMENTS AND THE POLITICS OF MEMORY}

course of this new Vergangenheitsbewältigung by comparing it to the experience of coming to terms with the legacy of Nazism. ${ }^{3}$ Although this comparative perspective promises to better our understanding of both dictatorial eras, other historical comparisons may be equally useful. By examining the Germans' attempts to "work through" earlier periods of their nation's burdened history, a broader understanding of German collective memory and its possible future development may be gained.

One area of considerable interest is the highly politicized collective memory of Germany's abortive revolutions of 1918-1919. This brief period constitutes one of the most turbulent eras in recent German history. Beginning with the collapse of the monarchy and the revolutionary proclamation of a republican form of government, what initially appeared to be a peaceful transition of power soon degenerated into bloodshed with the ensuing outbreak and violent suppression of radical left-wing attempts at revolution. In view of the dramatic nature of these events, it is no surprise that they occupy an important place in the collective memory of many Germans. The difficulties that succeeding generations have had in dealing with the memory of this era, in turn, attest to its historical importance and contemporary relevance. Indeed, the memory of this revolutionary era may well even have implications for the future development of the second Vergangenheitsbewältigung in a newly reunified Germany. Although the "working through" of the left-wing, revolutionary history of the German Democratic Republic is a topic that will be examined in full only by the next generation of historians, hints as to its possible course may emerge by analyzing the manner in which earlier episodes in the German revolutionary tradition have evolved in collective memory.

An excellent demonstration of the controversial place of the revolutions of 1918-1919 in German collective memory can be found in the city of Munich. As one of the main hotbeds (apart from Berlin) of revolutionary ferment after 1918, Munich was the site of traumatic events whose place in local memory has long been divisive. Already in the reactionary early years of the Weimar Republic, the era of revolution had become surrounded by legend and "distorted... until it was no longer recognizable." In the decades that have followed, both the revolutions of 1918-1919 and the figure most closely associated with them, Kurt Eisner, have con-

3. Bernd Faulenbach, Markus Meckel, Hermann Weber, eds., Die Partei hatte immer RechtAufarbeitung von Geschichte und Folgen der SED-Diktatur (Essen, 1994); Gotthard Jasper, "Vergangenheitsbewältigung': Historische Erfahrungen und politische Voraussetzungen," in Clemens Burrichter and Günter Schödl, Ohne Erinnerung keine Zukunft! Zur Aufarbeitung von Vergangenheit in einigen europäischen Gesellschaften unserer Tage (Cologne, 1992), 17-31; Jürgen Habermas, "Die Last der doppelten Vergangenheit," Die Zeit, 13 May 1994, p. 54.

4. Eberhard Kolb, "Foreword," in Revolution und Räterepublik in München, 1918/19 in Augenzeugenberichte, ed., Gerhard Schmolze (Munich, 1978), 9-10. 
tinued to spark dissension. So much so that the controversy surrounding the recent marking of the events' 75 th anniversary prompted hyperbolic comparisons to a Bavarian "historians' debate." The revolutionary era of 1918-1919 has remained a politically sensitive issue not merely in the city of Munich but also within the entire state of Bavaria, whose current, jealously-held republican identity as a Freistaat can be traced back to the period in question. The unsettled relationship toward the revolutions of 1918-1919 in Munich and throughout Bavaria thus reflects the existence of insecurities in both local and regional identity. Examining how this period of history has evolved in the collective memory of the citizens of postwar Munich, in turn, can shed light on the present as well as the past.

One of the most useful ways of analyzing the local memory of the revolutionary era involves examining the city's monuments that commemorate it. Recent scholarship on collective memory has confirmed the value of studying monuments. Ever since the pioneering French scholar of collective memory, Maurice Halbwachs, pointed out a half century ago that "collective memory unfolds within a spatial framework," scholars have begun to analyze systematically how memory is infused into urban space, particularly in the form of monuments. ${ }^{6}$ Spanning a wide array of objects-from stones and statues to plaques and street signs-monuments are paradoxical structures. Though erected for eternity with the intent of fixing the past permanently in physical form, they suffer from built-in obsolescence. For while monuments ostensibly are erected to commemorate some feature of the past, they actually offer a clearer image of the present's view of it. And inasmuch as this view inevitably evolves over time, the status of most existing monuments is subject to reappraisal-as manifested by their demolition, alteration, or replacement. By examining the variety of responses toward monuments over time, therefore, the evolving nature of memory reveals itself. $^{7}$

5. Christian Schneider, "Historikerstreit auf bayerisch," Süddeutsche Zeitung (SZ). 6/7 November 1993, p. 3.

6. Halbwachs further notes, "we can understand how we recapture the past only by understanding how it is ... preserved in our physical surroundings." Maurice Halbwachs, The Collective Memory (New York, 1980), 140. Since Pierre Nora's work on the subject, other scholars have focused on the relationship between monuments, memory, and identity. See, among many oth $\rightarrow$ Pierre Nora, "Between Memory and History: Les lieux de mémoire," Representations (Spring, 1989): 7-25; John Gillis, ed., Commemorations: The Politics of National Identity (Princeton, 1994); James Young, The Texture of Memory: Holocaust Memorials and Meaning (New Haven, 1993); Yael Zerubavel, Recovered Roots: Collective Memory and the Making of Israeli National Tradition (Chicago, 1995); Thomas Nipperdey, "Nationalidee und Nationaldenkmal in Deutschland im 19. Jahrhundert," Historische Zeitschrift 3 (1968): 529-85.

7. Halbwachs's assertion that memory is fundamentally rooted and preserved in social relationships-indeed, that it is condemned to oblivion without them-raises questions as to its dissemination over time. The apparent difficulty in accounting for the passing on of 
The shifting memory of the revolutionary era of 1918-1919 in postwar Munich is best analyzed by studying the wide range of responses toward the monuments commemorating it. The erection of new monuments as well as the demolition, restoration, or relocation of old ones reveal numerous insights into the dynamics of memory. With respect to these various types of responses, an analytical strategy combining a formal and "biographical" analysis offers the most comprehensive manner of understanding the role of monuments in the formation of memory. ${ }^{8}$ This approach focuses upon the object and the manner of commemoration as well as its origins and reception. The degree of selectivity displayed in choosing what is to be commemorated and what is to be omitted constitutes the first issue of consideration. Understanding how the past is commemorated requires studying the monument's formal qualities; whether it is abstract or figurative, whether or not it possesses a textual inscription, as well as the wording of that inscription, its size and location (both affecting its public visibility) bears heavily on a monument's ability to convey an intended message. Moreover, the question of agency and intent-who erected a monument and why-provides insights into the monument's significance. Finally, its popular reception-especially the presence of debate or controversy surrounding a monument's erection-yields perhaps the clearest insights into collective memory.

Before examining the various responses to monuments pertaining to the revolutions of 1918-1919 in postwar Munich, however, it is necessary to discuss briefly the history of the period itself. Since the memories of this important period have frequently diverged from the historical record, discussing the era's central events provides some standard by which to evaluate their evolution in memory. Since this undertaking is necessarily dependent upon the interpretations of historians who are themselves embedded in their own and their era's particular concerns, reconstructing the events of the past requires maintaining a critical eye toward underlying historiographical agendas. ${ }^{9}$ Nevertheless, for all of the recent insights

memory once its original bearers, those who personally experienced events, have themselves passed on, however, is addressed by pointing to the existence of "communities of memory," groups who empathetically identify with, and assign meaning to, events of the past through various commemorative ceremonies and gestures. Iwona Irwin-Zarecka, Frames of Remembrance: The Dynamics of Collective Memory (New Brunswick, 1994), 47-49; Paul Connerton, How Societies Remember (Cambridge, 1989), 37-40.

8. James Young refers to a "biographical" approach to monuments, Young, The Texture of Memory, ix.

9. The Bavarian revolutions sparked the most historical studies during the 1960 s and 1970s and have tailed off as of late. The subject acquired the most interest among East German historians who, like Hans Beyer, aimed to demonstrate the existence of mass working-class support for the second Räterepublik, Hans Beyer, Von der November Revolution zur Räterepublik in München (Berlin, 1957). An opposing view can be found in Allan Mitchell's, 
into the blurred boundaries between history and memory, the two ultimately emerge as distinct. ${ }^{10}$

Although historians have focused more on the course of revolutionary events in Berlin, the history of the revolutionary era in Bavaria is arguably more intriguing. In many ways, early twentieth-century Bavaria was an unlikely setting for political revolution. Ruled by the longest uninterrupted monarchy in Europe, the Wittelsbachs, and dominated by the Catholic Church, Bavaria was a seemingly stable political entity firmly in the hands of conservative forces. However, as Allan Mitchell has concisely put it, after World War I, "Bavaria was the first of the German states to become a republic and the last to be released from the grip of radicalism." 11 Indeed, for almost exactly six months, from 7 November 1918 to the first days of May 1919, Bavaria experienced unprecedented political instability, from the fall of the monarchy to the appearance of four different leftwing governments, to the brief but bloody outbreak of civil war brought about by the intervention of "white" counterrevolutionary military forces.

Many complex factors contributed to this revolutionary turn in Bavarian history. The resistance of the monarchy to adopt overdue political reforms, the war-induced worsening of economic conditions, the existence of a growing and disaffected working class, and the resulting increase of support for the SPD, as well as the general war weariness all helped to create an atmosphere of acute political discontent in Munich. ${ }^{12}$

Revolution in Bavaria, 1918-1919: The Eisner Regime and the Soviet Republic (Princeton, 1965) which, though clearly oriented toward debunking east bloc historiography, is the best work in the fairly scant English-language literature on the subject. See also Richard Grunberger, Red Rising in Bavaria (London, 1973). Recent attention toward Kurt Eisner's role in the period has been particularly promoted by the work of his granddaughter, the journalist Freya Eisner, who has been motivated by the desire to overturn left-wing and right-wing stereotypes about Eisner's political career. See, most recently, Freya Eisner, "Kurt Eisners Ort in der sozialistischen Bewegung," Vierteljahreshefte für Zeitgeschichte (July, 1995): 407-37. See also Rudolf Herz and Dirk Halfbrodt, Revolution und Fotografie, München 1918/19 (Berlin, 1988).

10. For other works on history and memory, see Patrick Hutton, History as an Art of Memory (Hanover, NH, 1993); Richard Terdiman, Present Past: Modernity and the Memory Crisis (Ithaca, 1993; Jacques Le Goff, History and Memory (New York, 1992). See also the journal, History and Memory: Studies in Representation of the Past. For the purposes of this brief essay, the following simplified distinctions between history and memory can be offered: history is the reconstruction of the past in written form by historians; memory represents how the past (as well as how written history) is perceived by society. Whereas the past is forever fixed, both history and memory evolve over time, with neither attaining an absolute or objectively "true" understanding of the past. This is not to say that history and memory are equally subjective, for their standards of reconstructing the past are very different. Still, although history has traditionally aimed (at least until recently) for a high degree of scientiftc objectivity, the opposition made by Halbwachs and others between a scientific history and "subjective" view of the past represented by memory can no longer be accepted.

11. Mitchell, Revolution in Bavaria, 5.

12. Ibid., 11-20. The creation of new war-related industries in the city after 1914 (especially 
It was the pivotal role of Kurt Eisner, the head of the Munich USPD (Independent Socialists), in guiding this discontent in a revolutionary direction that proved decisive. Eisner, a resident of Munich since 1910, had opposed the war from the beginning and had gradually won support for his revolutionary aims. On 7 November 1918, the extent of local support for Eisner became clear at the enormous peace demonstration organized by the socialist parties and trade unions at Munich's Theresienwiese; after delivering a speech criticizing the Bavarian government in front of some 50,000 people, Eisner led a sizable band of soldiers, workers, and other radicals in a march through the city that culminated in the forced occupation of the Bavarian Landtag. ${ }^{13}$ There, before a large crowd, Eisner declared the monarchy deposed and proclaimed the creation of the "Freistaat Bayern," the new Bavarian republic. ${ }^{14}$ With King Ludwig III and his family gone and billowing red flags draped from the city's main cathedral, the Frauenkirche, the revolution appeared to have been a success.

The success of the revolution, however, was short-lived. Several months after having acquired the position of prime minister, Eisner ran into political difficulties with his SPD coalition partners over their opposition to the future participation in the governance of the state of the revolutionary workers and soldiers' councils, or Räte. Forced to bow to the demands of the moderate SPD, however, Eisner lost the support of the more radical anarchists and communists. This fragmentation of the Left contributed to the USPD's poor showing in the elections of 12 January 1919 which, in addition to worsening economic problems and growing right-wing agitation by extremist groups such as the Thule-Gesellschaft, led Eisner to decide to tender his resignation in the hope of restoring political order. ${ }^{15}$

The restoration of political stability, however, was doomed by the as-

the Krupp works in the northern districts) dramatically increased the size of Munich's working class, a development that lent new support to the SPD and its constitutional reform efforts. Ibid., 20-29.

13. Ibid., 89-101; Schmolze, Revolution und Räterepublik, 85-110.

14. The oft-cited line read by Eisner was: "Fortan ist Bayern ein Freistaat" (From this moment on, Bavaria is a republic). As will be seen, the use of the term Freistaat would be highly controversial in postwar Munich. Rathaus München/Direktorium, Stenographischer Sitzungsdienst (RMDSS)/RP, Bauausschuss, 2 February 1989, 27-34.

15. Compared to the SPD's 33 percent of the vote, the USPD received only 2.5 percent. The fact that the BVP, the postwar incarnation of the Catholic Center Party, received the highest electoral total of 35 percent indicates the general degree of conservatism in Bavaria. Mitchell, Revolution in Bavaria, 217-18. The Thule-Gesellschaft was the most active in organizing propagandistic smear campaigns against the Eisner regime as well as more drastic actions ranging from espionage and kidnapping to paramilitary insurrection. Hermann Wilhelm, Dichter, Denker, Fememörder: Rechtsradikalismus und Antisemitismus in München von der Jahrhundertwende bis 1921 (Berlin, 1989), 57-76. 
sassination of Kurt Eisner on 20 February 1919 by a twenty-two year old ex-lieutenant, Count Anton von Arco auf Valley, in front of the Palais Montgelas on the Promenadestrasse in Munich's Altstadt. This single act of political violence, committed by a man of strong right-wing and antiSemitic convictions, radically transformed the Bavarian political scene. ${ }^{16}$ Following further assassination attempts against Bavarian Landtag members the same day, a new radical government, or Zentralrat, dominated by the left-wing parties and Räte, seized power under the leadership of Ernst Niekisch and declared martial law. ${ }^{17}$ By early April, however, the inability of the new government to restore order led to the occurrence of two additional revolutions. On April 7, a group of idealistic anarchists, including Niekisch, Ernst Toller, Gustav Landauer, and Erich Mühsam, proclaimed the creation of a Bavarian Soviet Republic (Räterepublik) in the hope of spreading "world revolution." This government lasted less than a week, however, at which time the communists, led by Eugen Leviné and Max Levien, replaced what they dismissed as the "pseudo-Soviet Republic," (Scheinräterepublik) with a second, genuine Soviet Republic. ${ }^{18}$

The violent suppression of the second Räterepublik by "white" military forces in early May 1919 brought to a bloody end the six-month period of revolutionary activity in Munich. As in Berlin, where the SPD-led republican government cooperated with the conservative military in crushing the Spartacist uprising in January 1919, the Munich SPD leader, Johannes Hoffmann, together with hardline SPD Reichswehrminister Gustav Noske, ordered the retaking of the city by a coalition of government troops and right-wing Freikorps units, commanded by the Prussian general Ernst von Oven. Having already engaged in atrocities on the outskirts of the city, the invading 35,000 man army launched into a vengeful campaign of murder upon hearing news of the retaliatory execution of ten hostages (including eight members of the Thule-Gesellschaft and two Freikorps soldiers) by "red" troops at the Luitpoldgymnasium south of the Altstadt. In the following days, "white" troops indiscriminately killed over 600 people in the city, particularly in left-leaning, working-class neighborhoods such as Giesing. ${ }^{19}$ Among the most prominent victims were Gustav Landauer,

16. It has often been speculated that Arco-Valley killed Eisner for complex psychological reasons due to his own anti-Semitic self-hatred. Born of a Jewish mother (from the Cologne Oppenheimer banking family), Arco-Valley had been rejected for membership in the Thule-Gesellschaft because of his "impure" background-a fact that, according to many, led him to assassinate Eisner as proof of his racial trustworthiness. Wilhelm, Dichter, Denker, Fememörder, 62; Schmolze, Revoltion und Räterepublik, 227-29.

17. Albert Schwarz, "Die Zeit von 1918 bis 1933," in Handbuch der Bayerischen Geschichte, ed. Max Spindler, vol. 4 (Munich, 1974), 428.

18. Mitchell, Revolution in Bavaria, 303-19; Grunberger, Red Rising, 111-14.

19. The total death figures vary. Hans-Günther Richardi has claimed that between 30 April and 8 May 1919, some 557 people were killed. "Die kurze Herrschaft der Räte in 
who was beaten to death and "Red Army" chief, Rudolf Egelhofer, who was fatally shot. Following subsequent trials, Eugen Leviné was executed for treason while the other revolutionary leaders received jail sentences of varying lengths.

Although the Bavarian Soviet Republic's existence was brief, its longterm effects were considerable. Immediately following the crushing of the Left, Bavaria became a bastion of right-wing political radicalism. In March 1920 , a Reichswehr-led putsch brought to power Gustav von Kahr, who subsequently turned Bavaria into a so-called Ordnungszelle-a haven for all the existing right-wing, militaristic, monarchistic, and antirepublican forces in Germany. ${ }^{20}$ This reactionary atmosphere, more importantly, provided fertile ground for the emergence of the Nazi Party, many of whose future members had actively opposed the Eisner regime. ${ }^{21} \mathrm{Up}$ until, and even following, Hitler's failed putsch at the Feldherrnhalle on 9 November 1923, the NSDAP gained considerable political support in the city. ${ }^{22}$ And although support for the Nazis subsequently declined in Munich, the party's early success earned the city the loyalty of Hitler and the official title, "Capital of the Movement," "Hauptstadt der Bewegung," in 1935. In short, Munich's chaotic experience of left-wing revolution promoted the ascendancy of the radical Right and helped make the city the birthplace of the most fateful political movement in modern German history. ${ }^{23}$

München," $S Z, 7$ April 1994, p. 35. Others cite figures of over 700 , if not 1000 . Hans Nöhbauer, München: Eine Geschichte der Stadt und ihrer Bürger vol. 2. Von 1854 bis zur Gegenwart (Munich, 1992), 206; Schwarz, "Die Zeit," 432.

20. Wilfried Rudloff, "Auf dem Weg zum 'Hilter-Putsch': Gegenrevolutionäres Milieu und früher Nationalsozialismus in München," in Stadtmuseum München, München- "Hauptstadt der Bewegung" (Munich, 1993), 36.

21. Among the future Nazis who opposed the Eisner regime and attempted to unseat the Räterepublik were former members of the Thule-Gesellschaft such as Dietrich Eckart, Hans Frank, Rudolf Hess, and Alfred Rosenberg, and Freikorps members, such as Franz Ritter von Epp and Ernst Röhm.

22. In national Reichstag elections, Munich support for the NSDAP began higher than the national total but later sank below it. Thus, in May 1924, 28.5 percent of all Münchner voted for the Völkischer Block (the successor party to the temporarily banned NSDAP), while only 6.5 percent of all Germans voted for it nationally; in May, 1928, the Nazis gained 2.6 percent of the total national vote, but 10.7 percent of the Munich vote; in September the figures were 18.3 percent nationally and 21.8 percent in the city; by July 1932 , however, the figures were 37.3 percent nationally and 28.9 percent locally, and by November 1932, the figures were 33.1 percent and 24.9 percent respectively. See Clemens Vollnhals, "Der Aufstieg der NSDAP in München, 1925 bis 1933: Förderer und Gegner," in: München-"Hauptstadt der Bewegung," 157-65; Richard Hamilton, Who Voted for Hitler? (Princeton, 1982), 144-55, 476; Klaus Schumann, "Kommunalpolitik in München zwischen 1918 und 1933," in Christoph Stölzl, Die Zwanziger Jahre in München (Munich, 1979), 1-17.

23. See the catalogue for the eponymous 1993-94 exhibition at the Munich city museum, München-"Hauptstadt der Bewegung," (Munich, 1993) for the most comprehensive view of the relationship between the city and the movement. See also Björn Mensing and Friedrich Prinz, Irlicht im leuchtenden München? Der Nationalsozialismus in der "Hauptstadt der 
The political upheaval caused by the revolutions of 1918-1919, in turn, has had the unavoidable effect of politicizing their place in collective memory. From the beginning of the Weimar Republic to the present postwar period, opposing memories of Kurt Eisner and the Bavarian revolutions of 1918-1919 have competed fiercely with one another in Munich. During the Weimar period, both the Left and the Right commemorated the turbulent revolutionary era in highly partisan fashion, with each claiming their respective martyrs. After 1933, however, the Nazis attempted forcibly to erase the prior competition of memories and impose an official mnemonic consensus. This was the period in which distortions of the historical record, extant since the Weimar era, were firmly canonized and the myth of Kurt Eisner as the demonic architect of revolutionary violence and civic chaos was enthroned as the standard view of the past. In contrast to this rather predictable development of memory in the Third Reich, the postwar era has witnessed the return of the politicized contestation of memory as well as its dynamic expansion. Since 1945, the liberal and conservative views of Kurt Eisner and the revolutions of 1918-1919 formed in the Weimar era have once more competed against one another. A new feature of these views of the past is their refraction through the recent experience of the Third Reich. To a degree, the distorted Nazi myths of Eisner and the revolutions of 1918-1919 were retained by the postwar society, especially among conservative citizens. Left-wing Münchner, meanwhile, frequently linked the revolutionary era to the Third Reich in a didactic manner, using the events of 1918-1919 to impart lessons about the dangers of fascism. Despite the incessant competition of these opposing views, however, the years since 1945 generally have witnessed the yielding of the conservative perspective to the more liberal one. In the process, a view dominated by historical myths has yielded considerably to one which more closely resembles the historical record. This, of course, is not to deny the partisan nature and selective vision of both perspectives; neither, however, is it to equate their subjectivity. Whereas the conservative view generally has attempted to deemphasize the place of Kurt Eisner and the revolutions of 1918-1919 in local memory, the liberal view has attempted to increase it. The influence of this latter position, in turn, is confirmed by the increasingly explicit pattern of commemorating the revolutionary past in local monuments. Nevertheless, despite this apparent "progress" in coming to terms with a difficult past, the continuing existence of dissension surrounding its legacy reveals that the proverbial "Schlußstrich" has by no means been drawn.

During the Weimar Republic, left-wing supporters of Kurt Eisner and the Bavarian revolutions took the most active role in commemorating their legacy in the city. The first commemorative act occurred on the very 
day of Eisner's assassination, 21 February 1919, in the form of a spontaneous memorial erected in front of the murder site at the Palais Montgelas on the Promenadestrasse. Immediately after Eisner's death, unknown persons scattered sawdust over the remaining pool of blood and placed a chair behind it adorned with a picture of Eisner and a black ribbon of mourning. Other passersby, most notably soldiers, stacked assorted rifles in the form of a pyramid at the site, which still others decorated with flowers and wreaths. Capped with a sign that read "Proletarians, remove your hat before the blood of Eisner," the provisional monument was visited by thousands of Münchner and attested to Eisner's new and unlikely status as a "Bavarian folk hero." ${ }^{24}$ Indeed, the attendance of over 100,000 people in the funeral procession on 26 February 1919 provided further proof of his local standing. This monument, however, would only be a provisional one that lasted until the chaotic month of April 1919. ${ }^{25}$

Following the burial of Eisner's ashes in Munich's Ostfriedhof, his leftwing supporters adopted more permanent commemorative measures. On the second anniversary of the Bavarian revolution on 7 November 1920, the local SPD leadership, together with labor union leaders, unveiled a bronze plaque bearing a relief of Eisner and the words, "To Kurt Eisner, the fallen fighter for freedom and truth, from his comrades," in the court of both groups' central headquarters on the Pestalozzistrasse. ${ }^{26}$ Two years later, on 1 May 1922, the same left-wing coalition commemorated a more somber occasion, the third anniversary of the crushing of the Bavarian Soviet Republic, by unveiling a large cubic monument dedicated to Eisner, as well as to the victims of the revolution of 1919 , at the Ostfriedhof. The selection of this particular site was not incidental; as the Ostfriedhof was the cemetery nearest to Munich's solidly working-class and left-leaning neighborhood of Giesing, it provided the most politically appropriate location to acknowledge the sacrifices made by the population on behalf of the revolution. The monument clearly articulated the Left's memory of the revolutionary past. Containing an urn bearing Eisner's ashes, the "Revolutionsdenkmal" was graced with a bronze plaque commemorating Eisner, as well as two accompanying texts on its front and rear sides. While the front exhibited the words, "To the dead of the revolution of

Bewegung" (Regensburg, 1991); Anthony Nicholls, "Hitler and the Bavarian Background to National Socialism," in: German Democracy and the Triumph of Hitler, ed. Anthony Nicholls and Erich Matthias (London, 1971), 99-128.

24. Schmolze, Revoltion und Räterepublik, 240-42; Freya Eisner, "Zwischen Kapitalismus und Kommunismus," Die Zeit, 18 February 1994, p. 74; Allan Mitchell refers to this memorial as a "pagan altar," 275; Grunberger, Red Rising, 80; Herz and Halfbrodt, Revolution und Fotografie, 119-24.

25. Herz, Revolution und Fotografie, 120.

26. Ibid., 301. 
1919," the rear displayed a quotation by Ernst Toller: "He who prepares the paths, dies on the threshold, but death bows before him in honor." 27 Finally, sometime later in the decade, the Bavarian state erected a third plaque in memory of Eisner at the site of his murder on the outer wall of the Palais Montgelas. ${ }^{28}$ All of these monuments clearly demonstrated the existence of local respect for the slain prime minister.

The Right, however, represented the revolutionary era in a much different manner. Instead of commemorating Eisner, it concentrated on commemorating its own dead claimed by the revolution. In September 1919, a plaque to the eight Thule-Gesellschaft hostages killed by "red" troops at the Luitpoldgymnasium was erected on the exterior wall against which they were shot. Sponsored most probably by the right-wing Deutschvölkische Schutz-und Trutzbund and the Thule-Gesellschaft, the text read: "Ernst Berger, Anton Daumenlang, Walter Deike, Walter Neuhaus, Wilhelm Seydlitz, Freiherr Karl Teuchert, Prinz Gust. Thurn und Taxis, Gräfin Hella Westarp died at the hands of the dastardly on April 30, 1919." Ten years later, an amended version of this plaque was erected including the names of the two Freikorps soldiers who, like the other eight hostages, were killed at the Luitpoldgymnasium. ${ }^{29}$ These right-wing monuments, together with their left-wing counterparts, indicate that the Weimar era was a divisive one that witnessed the competition of memories of the recent revolutionary past.

The rise of the Nazis to power in 1933 led to the drastic reformulation of Munich's revolutionary past in collective memory. Given their extreme hatred of Eisner and the revolutions of 1918-1919, the Nazis quickly undertook efforts to purge the physical reminders of the past from the city. ${ }^{30}$ On 22 June 1933, Nazi city councilmen Hans Zöberlein and Christian Weber attacked the Ostfriedhof Revolutionsdenkmal as an "eyesore" for

27. Thomas Guttmann, ed., Giesing: Vom Dorf zum Stadtteil (Munich, 1990), 176-79, 259. See Herz and Halfbrodt, Revolution und Fotografie, 11, for a photograph of the monument. The bronze plaque read: "Kurt Eisner, born 14 May 1867. Died 21 February 1919." Herz and Halfbrodt, Revolution und Fotografie, 301.

28. Little evidence exists of the actual plaque. The Munich Stadtarchiv possesses no records of it; the few references to it appear after 1945 with the attempts of certain city councilmembers to restore it. Stadtarchiv München/Ratsitzungsprotokolle (StAMü/RP), Stadtrat, 14 January 1947, 190-91; 21 January 1947, 289-98. Letter to author from Dr. Helmuth Stahleder, Stadtarchiv München, 2 January 1996.

29. Letter to author from Dr. Helmuth Stahleder, Stadtarchiv München, 2 January 1996. I am indebted to Dr. Stahleder for his assistance in tracking down the origins of this plaque. The date of this monument is the most likely one, but it may have been erected in 1933. For the slightly amended text see August Alckens, München in Erz und Stein: Gedenktafeln, Denkmäler, Gedenkbrunnen (Mainburg, 1973), 46.

30. In Mein Kampf, Hitler refers to Eisner as having acted "solely as a servant of the Jews" who were trying to make the Reich "fall ... prey to Bolshevism." Adolf Hitler, Mein Kampf (New York, 1971), 557. 
"all good Germans" and called for its removal from the cemetery "as a self-evident matter of honor." Like the Nazis' destruction of Walter Gropius's expressionist monument to the victims of the Kapp Putsch in Weimar and Ludwig Mies van der Rohe's monument to Rosa Luxemburg and Karl Liebknecht in Berlin after 1933, the demolition of the Revolutionsdenkmal on 22 June 1933 constituted an act of deliberate political intimidation. Zöberlein was a representative of the working-class neighborhood of Giesing and undoubtedly intended the demolition of the monument as a clear message to its left-leaning inhabitants. The Nazis' destruction of plaques to Eisner on the Promenadestrasse and the Pestalozzistrasse also drove this point home. ${ }^{31} \mathrm{~A}$ second factor underpinning the destruction of the Revolutionsdenkmal was anti-Semitism. At the same time that Eisner's ashes were removed from the Ostfriedhof, the city council decided to remove the ashes of Gustav Landauer from the Waldfriedhof, or Forest Cemetery. Zöberlein justified this measure by arguing that, "the Christian citizenry does not want the ashes of their relatives to be interred with those of the Jews Eisner and Landauer." The expulsion of the two Jewish revolutionaries demonstrated, according to Zöberlein, that "we as Christians, Bavarians, and Germans do not want to be in a community with Jews." ${ }^{32}$ With these measures, Nazi hatred of the Jews and of the Left found clear expression.

The Nazis' efforts to extinguish the memory of the revolutions of 19181919 completely, however, were not wholly successful. The demolition of the Ostfriedhof monument paradoxically led not so much to the total elimination of memory but to its diminution through spatial transferral. Eisner's remains were ordered reinterred in the new Jewish cemetery in Schwabing together with those of Gustav Landauer, their graves marked with a new simple stone bearing their names. ${ }^{33}$ The memory of the revolutionary era, marginalized in the peripherally-located, textually-mute stone, was essentially banished from public view. Nevertheless, in this new monument "created" by the Nazis, it maintained a precarious if private existence.

The Nazis, however, did not content themselves with eliminating the already existing monuments to the revolutions of 1918-1919 but erected their own revisionist versions of the past as well. The first move taken by the local Nazi leadership occurred in April 1933 with the renaming of

31. Guttmann, Giesing, 176-79. As one Nazi councilman argued, "the memory of Kurt Eisner will remain preserved by the people ... as a deterrent example for those who are inclined to harm the state." Herz and Halfbrodt, Revolution und Fotografie, 301.

32. Herz and Halfbrodt, Revolution und Fotografie, 301.

33. Karl W. Schubsky, "Jüdische Friedhöfe," in Synagogen und jüdische Friedhöfe in München, ed. Wolfram Selig (Munich, 1988), 186. 
the Promenadeplatz into the Ritter-von-Epp-Platz (after the Freikorps leader, Franz Ritter von Epp who was instrumental in leading the suppression of the second Räterepublik). ${ }^{34}$ The choice of this site was no doubt deliberate; since it fronted the site of Eisner's assassination on the Promenadestrasse, the new name clearly asserted the Right's occupation and reconstitution of a historic site of the Left. Several years later, the local Nazi leadership appropriated the memory of the right-wing hostages executed by the red troops at the Luitpoldgymnasium in April 1919. In October 1936, a plaque to the two Freikorps soldiers killed was erected at the site that read: "Here, on April 30, 1919, the government soldiers Linnebrügger, Fritz, father of five children, 41 years old, and Hindorf, Walter, 19 years old, fell as defenseless prisoners at the hands of murderers." ${ }^{35}$ That same year, the Nazi-led city council attempted to create further sympathy for the "martyrs" of the revolution by naming four streets in the neighborhood of Kirchtrudering after Thule-Gesellschaft members, Hella von Westarp, Franz Carl Freiherr von Teuchert, and Walther Deike, as well as the Freikorps soldier, Fritz Linnebrügger. ${ }^{36}$

The most dramatic expression of the Nazis' version of the Bavarian revolutions appeared in the form of the "Freikorpsdenkmal" in the neighborhood of Giesing. Designed by the sculptor Ferdinand Liebermann and erected at a busy traffic site, the Giesinger Berg, on 3 May 1942, the monumental stone structure was composed of a twenty-four foot high relief of a naked male figure strangling a snake symbolizing "degeneration and decline"; flanking the figure on an adjoining wall were the emblems and names of the 22 Freikorps companies that participated in the suppression of the Räterepublik in early May of $1919 .{ }^{37}$ Although the symbolism of the monument was fairly obvious - the heroic Right saving the Volk from the dire threat of the Left-its function was more significant. In the planning stages since 1937, the late date of the monument's completion testifies to the symbolic importance the Nazis assigned to it. The fact that it was finished at all is remarkable since the Second World War had halted many other construction projects sponsored by the regime. Most likely, as with the demolition of the Revolutionsdenkmal at the Ostfriedhof, the Nazis intended the Freikorps monument to remind the working-class inhabitants of Giesing of the Right's dominance over the Left not only in the past but in the present as well.

34. Kurt Preis, München unterm Hakenkreuz, 1933-1945 (Munich, 1989), 30-31.

35. Alckens, München in Erz und Stein, 46.

36. See Hans Dollinger, Die Münchner Strassennamen: $Z u$ Fuss durch die Geschichte unserer Stadt (Munich, 1995), 121, 56, 179, 293.

37. Elisabeth Angermair and Ulrike Haerendel, eds., Inszenierter Alltag: "Volksgemeinschaft" im nationalsozialistischen München, 1933-1945 (Munich, 1993), 32; Guttmann, Giesing, 17679; Alckens, München in Erz und Stein, 41. 


\section{MONUMENTS AND THE POLITICS OF MEMORY}

After 1945, the experience of the Third Reich strongly affected the postwar memory of Kurt Eisner and the revolutions of 1918-1919. Although the revolutionary era had been traumatic in its own right, the far more dramatic events that followed it-in particular, the establishment of the Third Reich, the outbreak of the Second World War, and the extensive war damage suffered by the city of Munich-inevitably cast it in their shadow. As a result, the memory of the revolutionary era was increasingly refracted through the local memory of the Third Reich and the evolution of the memory of the events of 1918-1919 was both halted and propelled by attendant shifts in the memory of the Nazi era. As the latter was confronted more openly over time, so was the former. The memory of Kurt Eisner and the revolutionary era in Munich has thus been marked by an increasing willingness to abandon more prejudiced and subjective views of the past for a more balanced and nuanced perspective. This development found clear expression in the increasingly explicit pattern of commemorating Kurt Eisner and the revolutions of 1918-1919 in Munich. Beginning with the negative measure of demolishing unwanted Nazi monuments in the late 1940 s, the commemoration process shifted in the 1950s to more tentative positive acts, such as restoring destroyed monuments, and finally to the more direct attempts after the late 1960s to erect new monuments of increasingly forthright form, text, and location. And yet, despite this progressive process of normalization, the memory of the Bavarian revolutions of 1918-1919 has to this day remained highly politicized.

The first years after 1945 displayed the most reluctance to confront the memory of Munich's revolutionary past. During this period, it was far easier to overturn the Nazis' highly partisan view of the revolutions of 1918-1919 than to forge a consensus for remembering it. The initial and easiest measures were thus part of the general program of urban denazification decreed by the Allied occupation forces and undertaken by city agencies. ${ }^{38}$ The first relevant move was to grant the Promenadeplatz in the Altstadt its original name by eliminating its Nazi-era appellation, the Ritter-von-Epp-Platz. ${ }^{39}$ Interestingly, this was not repeated with the four Nazi-era streetnames to the victims of the "red" troops in 1919 which remained unaltered. This pragmatic strategy of selective decommemoration, moreover, also surfaced briefly with the postwar treatment of the

38. Under the terms of Allied Control Council Directive no. 30, "any monument... which tends to preserve ... the German military tradition... or to commemorate the Nazi party ... must be completely destroyed ..." "Directive no. 30," Official Gazette of the Control Council for Germany, no. 7 (31 May 1946): 154.

39. See "Umbenennung von Strassen und Plätzen," Münchner Stadtanzeiger, 26 September 1945, p. 3 and 3 October 1945, p. 3; Helmuth Stahleder, Haus-und Strassennamen der Münchner Altstadt (Munich, 1992), 24-25. 
Freikorpsdenkmal in Giesing. Although the emblems and Freikorps names were removed as symbols of militarism prior to 1 January 1947 in accordance with Allied denazification regulations, the monumental relief of the martial male figure itself remained standing. To be sure, little sentimental feeling existed within the local population toward the figure, which already during the Third Reich had been derisively referred to as "der nackerte Lackel," or "the naked oaf" (Figure 1). For a time, however, city officials seemed to consider preserving the figure for "artistic reasons." Nevertheless, in December 1946, the surfacing of complaints by local citizens and the energetic lobbying of the Communist city council faction (KPD) to demolish the entire structure ultimately proved decisive. Shortly thereafter, the remaining figure was torn down and the accompanying wall reduced in height to the level of the surrounding retaining walls. ${ }^{40}$

Although overturning the Nazi view of the past through such demolition projects was relatively easy, restoring the mnemonic status quo antethe Left's view of the past from the Weimar period-was more difficult. On 14 January 1947, the KPD city council faction demanded the restoration of the plaque to Eisner (removed by the Nazis after 1933) at the site of his murder on the Palais Montgelas. After a heated discussion, the city council referred the demand to the Bavarian state for consideration, at which point it was dropped altogether. While issues of bureaucratic jurisdiction were involved in this decision, one of its most important causes was the belief of numerous conservative members of the city council that "it was not advisable to preserve the memory of the Eisner era." Significantly, the desire of conservatives to avoid the memory of the past was itself founded on faulty memories of it. Mayor Karl Scharnagl, a member of the Christlich-Soziale Union (CSU), for one, argued that since "Eisner was not the democrat that everyone thought he was," it was unadvisable to "immortalize this truly regrettable affair for all eternity." Underlying this view was the assertion that "the acts of violence that occurred [during the Eisner era] ... were of such proportions ... that we do not believe they are worth remembering." 41 Scharnagl's identification of Eisner's regime with the revolutionary violence that followed after his assassination represented one of the most common distortions of the historical record in postwar memory. This conflation of historical events, moreover,

40. City building director Hermann Leitenstorfer gave his approval for the demolition after concluding that "artistic reasons for preserving [the figure] have receded in importance." StAMü/RP, Hauptausschuss, 13 February 1947, 174-76; "Gegen das FreikorpsDenkmal," Münchner Mittag, 20 December 1946, p. 5. In its place, a bronze sculpture by Josef Erber representing children at play, flanked by reliefs of scenes from local history, was erected in the fall of 1959. "Ein Kinderbaum ...," SZ, 27 October 1959, p. 4; Alckens, München in Erz und Stein, 73.

41. StAMü/RP, Stadtrat, 21 January 1947, 291. 
236 MONUMENTS AND THE POLITICS OF MEMORY

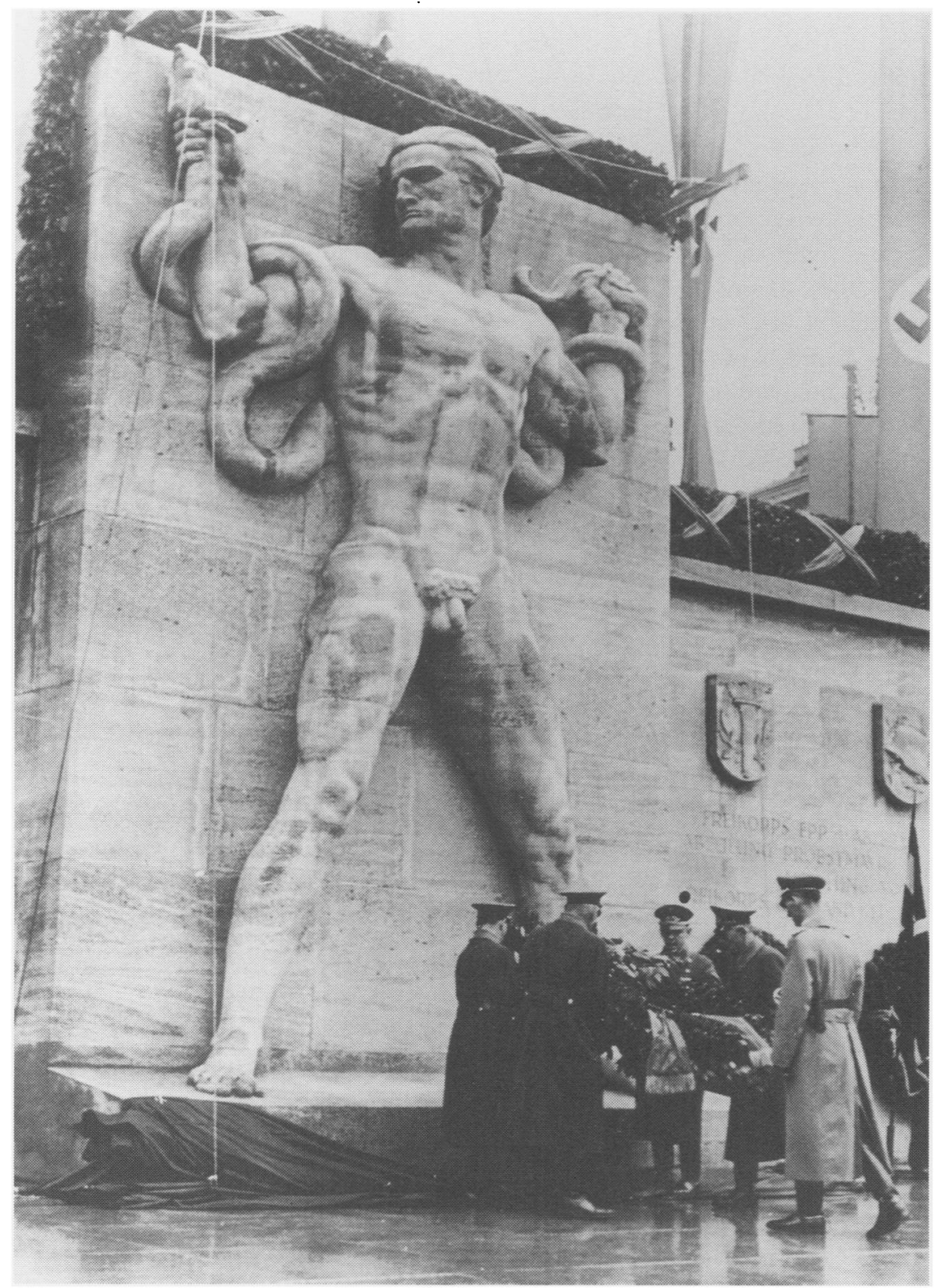

FIGURE 1: "Freikorpsdenkmal" in Giesing 
would surface repeatedly as the basis for resisting subsequent attempts to commemorate Eisner or the revolutionary era. In short, as indicated by the city council's reluctance to pursue energetically the restoration of the plaque to Eisner in 1947, negative memories of the slain prime minister contributed to the failure to restore his place in local memory. ${ }^{42}$

The 1947 city council debate further revealed that the political Left in Munich held a very different memory of Eisner and the Bavarian revolutionary era. During the debate, SPD and KPD city council members predictably defended Eisner's democratic credentials, asserted his innocence for the violence that occurred after his murder, and demanded the restoration of the plaque as an act of "reparations" for the deeds of the Nazis. In so doing, they adhered more closely than conservatives to the historical record. Not only did they carefully distinguish between the frequently blurred facts of the period, they perceptively noted how "the considerable distance from the former era... had produced alterations in perspective" among the opposition. The Left, however, was no less partisan in its exploitation of the past for their own ends. In defending Eisner's reputation, the left-wing city council factions mobilized the recent history of the Third Reich on their behalf. SPD city councilman and union leader Gustav Schiefer, for example, attempted to bolster Eisner's democratic credentials by comparing him to the brave men of the famed Freiheitsaktion Bayern, or Freedom Action Bavaria (a group which had attempted unsuccessfully to topple the local Nazi regime in late April 1945); for Schiefer, Eisner had simply acted as a representative of "a healthy opposition that was committed to establishing new conditions." ${ }^{43}$ Although more rhetorical than substantive, the linkage of the revolutions of 1918-1919 with the resistance to the Third Reich aimed to give moral legitimacy to persons and events of the revolutionary past by asserting similarities between them and the few heroic resistance figures of the more recent Nazi past. More problematic than the SPD's drawing of analogies between the revolutionary era and the Third Reich, however, was its partial hypocrisy in defending Eisner. Indeed, after 1918, the SPD leadership had vigorously opposed Eisner, the head of the rival USPD, during his short administration and had eagerly hoped to govern in his place. The party's postwar loyalty to Eisner's legacy thus betrayed a selective memory as well, but in the early postwar era, this left-wing memory of the past was too weak to overcome conservative resistance to the recommemoration of Eisner and his revolutionary legacy.

Following the general reluctance to confront the past in the 1940s, the

42. The fact that the bill was sponsored by the KPD-a party soon to be banned nationwide as a result of cold war tensions-no doubt also hampered its passage.

43. StAMü/RP, Stadtrat, 21 January 1947, 294. 
late 1950s witnessed the first limited moves to commemorate Eisner and the events of 1918-1919. In 1958, the Munich city council ordered the partial reconstruction of the demolished Ostfriedhof Revolutionsdenkmal. The motivations behind this action are unclear; the fact, however, that the measure was tacked onto an extant bill to erect a monument in the Ostfriedhof to the political victims of the Nazi regime indicates that it may have originated as an afterthought, though a comparatively progressive one. That the effort to commemorate the victims of the Third Reich prompted the commemoration of the victims of 1918-1919 further demonstrates the postwar linkage between the two periods in local memory. The close proximity of the early postwar era to the events of the Third Reich no doubt led many to derive meaning from the earlier revolutionary era only insofar as it evoked similarities with the Nazi era that followed. This linkage, in turn, may have determined the inexact manner in which the Revolutionsdenkmal was restored. Since neither remnants nor design drafts of the original were to be found, the monument's form had to be reconstructed according to the memory of the local sculptor, Konstantin Frick. More significantly, the city council decreed that the original texts were not to be reproduced in full; the only words that graced the reconstructed monument, therefore, were: "To the dead of the revolution of 1919." The reference to Eisner was omitted as was Ernst Toller's quotation. With such vague wording, the effect of the monument in preserving the memory of the events of 1918-1919 was minimal; since the identity of "the dead" was left undetermined, one could have just as easily interpreted them to be Freikorps soldiers as left-wing sympathizers of the revolution for whom the monument was originally intended. It is difficult to know whether such ambiguity was intended. The Revolutionsdenkmal's resemblance to many textually vague monuments erected in the Federal Republic to the victims of Nazism in the 1950s, however, seems to indicate an underlying desire to avoid a direct confrontation with the past. As with these postwar monuments, the refusal of the Revolutionsdenkmal to identify "the dead" reflected the era's tendency to unite victim and perpetrator together in a gesture of forced reconciliation. ${ }^{44}$ As such, the impact of the Third Reich upon postwar habits of commemoration seems to have influenced the memory of the revolutions of 1918-1919.

In the 1960s, however, a dramatic shift occurred in the commemoration of Eisner and the Bavarian revolutionary past. In the preceding decade, local city officials had attempted little more than the adaptive restoration

44. StAMü/RP, StR, Aktensammlung, 22 April 1958, 1326. In light of this bill, assertions that the monument was restored in 1945 appear to be in error. See Guttmann, Giesing, 176-79, 259 and "Die Inschrift und das Vermächtnis aufpoliert," $S Z, 23$ May 1989 , p. 15. 
of older Weimar monuments to Eisner. The 1960s, however, witnessed the postwar era's first attempts to fashion its own strategies of commemorating the past. The marking of the 50th anniversary of the events of 1918-1919 in 1969 stimulated new commemorative measures. The most ambitious, but least successful, occurred on February 21, the anniversary of Eisner's assassination, with the erection of a plaque on the site of his murder at the Palais Montgelas bearing the text: "Kurt Eisner was murdered on this spot fifty years ago." Since the plaque's sponsors, a left-leaning citizens' group (led by union leader and councilman Ludwig Koch as well as Eisner's granddaughter, Freya Eisner) did not get permission for a permanent monument at the site, the provisional plaque was removed shortly after its erection. ${ }^{45}$ The most controversial measure of 1969 , however, erupted one month earlier in January with the debate over naming a street after Kurt Eisner in the outlying neighborhood of Neuperlach. Originating as an SPD bill in the city council to mark the occasion of the 50th anniversary of Eisner's death, the proposal to create a Kurt-Eisner-Strasse was linked to the suggestion to name one after Karl Marx. Significantly, it was not the latter proposal but the former that became the focus of controversy.

As demonstrated by the conservative CSU's objection to the bill, the memory of Eisner and the revolutionary era remained burdened by numerous conflations and omissions. Overall, the representatives of the CSU argued that the memory of the revolutions of 1918-1919 deserved to remain suppressed. This position, not surprisingly, was based upon the familiar, if faulty, view of the past that blamed Eisner for the violent end of the revolutionary era. As CSU councilwoman Haas argued, Eisner had been a "communist" who was guilty of "creat[ing] ... a Soviet Republic according to the Russian model." ${ }^{46}$ This erroneous statement summed up the general conservative belief that "what Eisner and his following wanted led, in the end, to the Reich government's... [intervention] and the result of 700 dead." 47 Operating according to this view, CSU council members predictably tried to justify their opposition to the proposal by making the populist claim that the name of Eisner "was associated in the minds of the local citizenry with great disaster." According to CSU councilman Hans Stützle, this was a period that "had not yet been worked through" and had left "wounds that have not yet healed." "Naming a

45. Photo with caption, $S Z, 22 / 23$ February 1969 , p. 15 . As indicated by a local citizen's demand (in a letter to the editor in the Süddeutsche Zeitung at this same time) to restore of the original plaque at the site (demolished by the Nazis), the Weimar-era monument had clearly persisted in local memory. "Eisners Andenken ehren," $S Z, 21$ February 1969, p. 12.

46. StAMü/RP, Hauptausschuss, 14 January $1969,6-21$.

47. StAMü/RP, Stadtrat, 15 January 1969, 66-95. 
street after Eisner," he asserted, "would rip them open anew." As a concrete, if bizarre, example of the problems entailed with confronting the past, Stützle cited the case of the widow of Eisner's assassin, Graf ArcoValley, who as one of "the still living victims of that era," should be shown "consideration and respect" by waiting to enact such a measure "until one has greater distance in time from the former events." Conservative councilman Ludwig Schmid, in turn, drew the full policy implications of this assertion by concluding that, in light of the proposal's controversial nature, it would be better to abandon the practice of naming streets after individuals altogether and, instead, name them after "wonderful flowers, charming animals, or beautiful lakes." ${ }^{48}$ Politically motivated objections thus found expression in a depoliticizing impulse.

The responses of the SPD city council faction, in turn, displayed a more nuanced, if no less engaged, view of the past. Marshaling historical facts on their behalf, SPD councilmembers asserted Eisner's innocence of the violent suppression of the revolutionary era and cited numerous details in support of their position that "the things that occurred after Eisner's death were an effect of his murder." ${ }^{49}$ More interesting than the SPD faction's citation of historical fact, however, was its members' insights into the dynamics of memory. According to SPD representatives, the calumnies expressed toward Eisner were a product of a long period of revisionist "historical falsification." As councilman Ludwig Koch argued, although "the fact remains that during Eisner's regime, no acts of violence occurred,.... [n]either those who came after Eisner nor the dictators of the Third Reich attempted to display an objective depiction of Eisner's historical image." The result of the ensuing "falsification," councilman Fried added, was that "one is inclined today to adhere to this false view of history." Interestingly, SPD leaders partially agreed with members of the CSU that the dispute over Kurt Eisner had resulted from the continuing proximity to the historic events themselves. As Hans Preissinger noted, the persistence of "emotions and memories, of a personal and subjective nature" had strong political implications for historical understanding:

The closer contemporary history approaches politics, the more it is falsified by the passions of politics. We have enough distance from Marx who, active a hundred years ago, ... is viewed objectively, soberly and without emotion as a historic innovator of his time. In contrast, Eisner [is] still touched by contemporary history and falsified by political passions [and thus] lacks a well-rounded, fully-developed historical image. 
For Preissinger, however, it was the CSU that was especially guilty of promoting a faulty, "restorationist" view of the past for political gain. Although the CSU's representatives claimed the existence of widespread opposition to the measure among the local citizenry, it betrayed its partisan agenda, according to Preissinger, by defending the feelings of ArcoValley's widow - an act that implicitly "sanctioned the murder of Eisner." 50 The SPD, in turn, refused to allow the CSU to claim a popular mandate for its opposition to the bill. "You cannot speak of 'the population,", councilman Ludwig Koch accused the CSU, "because the segment of the population that strongly concerns me sees the history completely differently." His constituency, Koch stressed, still "remember[ed] the white troops and their murders," and thus understandably yearned "for a correction of the falsification of history." 51 In short, by the late 1960s, the collective memory of the revolutions of 1918-1919 still remained fragmented into opposing politicized versions.

The narrow approval of the SPD proposal to create a Kurt-EisnerStrasse in February 1969, in turn, sparked a brief, if intense, flurry of controversy within the local population of Munich. As demonstrated by letters to the editor received by the Münchner Merkur, which closely covered the issue, much of the local citizenry disapproved of the measure. According to the newspaper, some ninety percent of the more than 100 letters received within a week of the decision opposed naming a street after Eisner. ${ }^{52}$ Many of the comments confirmed the SPD's view of the existence of false stereotypes about Eisner and his legacy. Some referred to Eisner as a "Communist" and a "political muddle-head," who had paved the way for the Soviet Republic; as one citizen noted, "To dedicate a street after a man whose deeds for Bavaria were of such a catastrophic nature amounts to completing the anti-Bavarian nonsense of Eisner fifty years after the fact!" Another respondent articulated just how catastrophic Eisner had been for Bavaria by implying that his reckless overthrow of the monarchy had eliminated the city's resistance to political extremism and eased "the victory of National Socialism." Although it is unclear how widespread this view was among conservatives, other attempts to link Eisner to the rise of the Nazis were made by respondents who compared the city council's decision to name a street after him to the hypothetical creation of "an Adolf-Hitler or Heinrich-Himmler Street." Furthermore, scattered right-leaning comments peppered the responses, such as the demand by one citizen finally to honor the "Free Corps fighters

50. Ibid.

51. StAMü/RP, Stadtrat, 15 January 1969, 66-95.

52. "Leser schreiben uns," $M M, 23$ January 1969, p. 16. 
who gave their blood so that Munich could remain a free city." 53 Finally, the submission of a bill in the Bavarian Landtag by the far right-wing NPD party in early February objecting to naming a street "after the communist putschist, Kurt Kosmanowsky, called Kurt Eisner," betrayed the influence of classic anti-Semitic myths of Nazi propaganda and revealed the latent political direction of a portion of local opposition to the measure. ${ }^{54}$

The conflict over the Kurt-Eisner-Strasse in 1969, in short, demonstrated the existence of politically-determined differences in collective memory. Representatives of the CSU as well as members of its constituency exhibited selective and distorted views of the revolutions of 1918-1919 and chose to project the causes of the subsequent violent conclusion of the period back onto its relatively peaceful beginnings under Eisner. Choosing not to acknowledge or condemn Eisner's murder as the cause of later events, conservative citizens and politicians viewed him as a perpetrator. The SPD view, in contrast, offered a far more objective picture of the past, emphasizing the distinctions between Eisner's goals, his government, and the revolutionary events which followed his death. Yet, the SPD view was also underpinned by a convenient forgetting of their own position in 1918-1919. In view of the enmity and irreconcilable differences between the SPD and Eisner's USPD in 1918-1919, the former's postwar claims to protect his memory were, to say the least, ironic if not disingenuous. Still, while the SPD position was somewhat selective in nature, it served as a healthy corrective to the more problematic prejudicial alternative.

And yet, despite the creation of Kurt-Eisner-Strasse, the city of Munich still lacked a central monument to Eisner's memory fifty years after his death. The out-of-the-way location of the street in the outlying neighborhood of Neuperlach hardly served to preserve Eisner's memory in a public manner. For this reason, further commemorative impulses appeared in the 1970s. In mid-1973, the SPD-led city neighborhood committee for the Altstadt submitted a bill in the city council for the erection of a plaque for Eisner at the site of his murder. Planned for the eastern wall of the Palais Montgelas on the Kardinal-Faulhaber-Strasse (the old Promenadestrasse), the plaque was to read: "Palais Montgelas. The Bavarian Prime Minister, Kurt Eisner, was murdered in front of this building on February 21, 1919 (emphasis added)." Had it been approved, this plaque would have promoted a new degree of public awareness about the past.

53. "Starkes Echo zum Thema Strassennamen," MM, 18/19 January 1969, p. 10; “Leser schreiben uns,"MM, 23 January 1969, p. 16.

54. Bayerischer Landtag, 6. Legislaturperiode, 1966-1970, supplement 1794, Schriftliche Anfrage, NPD, 3 February 1969. Reminiscent of other anti-Semitic canards proclaiming the Jewish "identity" of leftist politicians, the charge that Eisner's name was Kosmanowsky lacks all factual basis. Freya Eisner, "Zwischen Kapitalismus und Kommunismus," Die Zeit, 18 February 1994, p. 74. 
Yet, a serious blow to this commemorative gesture occurred when the owner of the property rejected its erection on the site due to fears of vandalism..$^{55}$ As a result, when finally dedicated in late 1976, the plaque was relocated across the street, obscurely placed in the ground of the central, grassy strip of the Promenadeplatz frequently passed by trolley cars. More importantly, this shift required the following subtle but important amendment to the text: "In memory of Bavarian Prime Minister Kurt Eisner who was murdered on February 21, 1919 in front of the Palais Montgelas." Needless to say, the less visible site of the plaque separated it from the spot of the historic event (as did the replacement of the original words, "this building"-which would have clearly located the historic site in spatial terms - with "the Palais Montgelas," the location of which was far less clear); both features of the plaque, in turn, undermined its ability to preserve the past in memory. The only thing clearly expressed by the plaque was the continuing local ambivalence toward Eisner's legacy. As one left-wing labor union representative concluded, the undignified location of the monument "on the ground ... directly next to the trolley tracks... is an indication of how progressive traditions are dealt with in Bavaria." 56

The final controversies over Kurt Eisner and the Bavarian revolutions of 1918-1919 occurred in the 1980s. By 1985, the increasing belief that the recently erected plaque for Eisner was "unworthy" led to new attempts to create a more explicit monument at the actual site of his murder. ${ }^{57}$ Initially, however, the proposal for "a worthy monument in the form of a column" made by SPD city councilman Alfred Lottmann met with widespread rejection from conservative citizens groups and an outright veto by the CSU city council faction. ${ }^{58}$ Underlying the opposition were traditional resentments against Eisner. As the Bavarian Landtag representative and opponent of the measure, Richard Hundhammer, argued, Eisner did not deserve a monument since he had "propagated violence" and seized power "with a bunch of left-wing radicals, Communists, and anarchists." 59 Although this conflation of events was familiar, the public response to the measure's defeat expressed an unprecedented degree of anger. In a stream of critical letters to the editor in the Süddeutsche Zeitung in

55. "Wo Kurt Eisner ermordert wurde...," SZ, 9 November 1976, p. 19. This fear was not unfounded given the destructive attacks against a plaque dedicated to Lenin on the site of his former residence in Schwabing in 1970. Alckens, Giesing, 76.

56. Reimund Mess, Das andere München: DGB-Stadtrundfahrt (Munich, 1983), 27.

57. Letter from Hannes König, SZ, 6 September 1985, p. 20.

58. RMDSS/RP, Lottmann Antrag, no. 819, 20 August 1985; Bauausschuss, 24 October 1985, 382-85; Bauausschuss, 27 February 1986, Aktensammlung, 497-502. "Streit um Kurt Eisner," SZ, 27 August 1985, p. 9.

59. "Streit um Kurt Eisner," SZ, 27 August 1985, p. 9. 


\section{MONUMENTS AND THE POLITICS OF MEMORY}

the summer of 1985 , local citizens roundly denounced the false remembering of the past. Some adopted the traditional approach of staunchly defending Eisner's pacifism; others, however, adopted a provocative new strategy, charging that behind "the outcry against... erecting a monument to Eisner lay the ugly face of anti-Semitism." ${ }^{\circ 0}$ In large part, this new accusation surfaced in response to the report that representative Hundhammer had drawn upon an old Nazi strategy in referring to Eisner as "Kosmanowsky" in a letter to Munich mayor, Georg Kronawitter. This news, in turn, led other citizens to warn against "the acceptance of Nazi propaganda" and its timeworn claim that the revolution had been the work of "foreign elements of mostly Jewish blood." Indeed, in a subsequent city council debate, councilman Alfred Lottmann clearly articulated the need to stand firm against "the usual anti-Semitic falsifiers of history." ${ }^{61}$ The unprecedented attention to Eisner's Jewish identity as well as the widespread sensitivity toward anti-Semitism that suddenly surfaced in the 1980 s was most likely influenced by the wave of commemorations and controversies surrounding the 40th anniversary of the end of World War II in 1985-a time when the Bitburg affair and the celebrated speech of 8 May 1985 of Bundespräsident Richard von Weizsäcker represented two opposing poles of West German attempts of Vergangenheitsbewältigung. In any case, the new coupling of anti-Semitism with any opposition to commemorating Eisner contributed to the withering of resistance to the measure. Finally, in October 1985, the city council, led by the SPD and the Greens, overcame conservative objections and ultimately approved the bill. ${ }^{62}$

And yet, as preparations for the monument proceeded in the period that followed, the eruption of a new controversy demonstrated the continuing divisiveness of Eisner's legacy. ${ }^{63}$ By the fall of 1988, the city council's building committee had approved a design for a monument at the site of

60. Letter from Paul Walter, $S Z, 13$ September 1985, p. 16.

61. See letters from Gerald Engasser, Paul Walter, Peter Hendl, SZ, 13 September 1985, p. 16 and Heinrich Bihrle and Klaus Budzinkski, SZ, 25 September 1985, p. 16; "Noch kein Platz für Eisner-Denkmal," SZ, 25 October 1985, p. 15.

62. Opponents had claimed that insufficient space existed on the sidewalk site for a monument. RMDSS/RP, Bauausschuss, 24 October 1985, 382-85; Bauausschuss, 27 February 1986, Aktensammlung, 497-502; "Jetzt doch ein Denkmal für Kurt Eisner," $S Z, 31$ October/1 November 1985, p. 17.

63. While the commissioning of a monument would take several years to yield results, unconventional interim measures served to maintain the new interest in Eisner. On 21 February 1986, the anniversary of Eisner's death, members of the SPD-affiliated group, "The Other Bavaria," launched its action "the invisible monument," tearing up a flagstone in the Kardinal-Faulhaber-Strasse's sidewalk and burying a plastic painting of Eisner beneath it, before restoring the site's appearance. While the commemorative impact of this action was limited, it attested to a new impulse to recognize Eisner's symbolic importance. "Unsichtbares Denkmal für Kurt Eisner," $S Z, 23$ February 1986, p. 19; "Vom Problem, mit einer Inschrift Zeichen zu setzen," SZ, 3 February 1989. 
Eisner's murder. Created by the artist Erika Lankes, a cast-iron plate bearing the outlined likeness of a sprawled figure (similar to those drawn in chalk by police at a crime scene) was to be embedded in the pavement where Eisner had been shot. This proposal, by far the most visually compelling to be devised in the postwar period, however, soon became embroiled in controversy because of its accompanying text. Following discussions between representatives of the building committee and the Munich city archive, it was agreed to select the text: "Kurt Eisner, 1867-1919, prime minister of the Volksstaat of Bavaria, was shot here in front of his office headquarters on 21 February 1919." ${ }^{64}$ In response to this draft, SPD members of the city council issued a counter proposal protesting that, in fact, Eisner had been the founder and prime minister not of theVolksstaat but of the Freistaat of Bavaria and should be acknowledged as such in the text. ${ }^{65}$ This point of dissension, inconsequential on the surface, in fact gave significant insights into the conflicting memories of Eisner and the revolutionary past.

The question of whether Eisner should be acknowledged as the founder of the Volksstaat or Freistaat of Bavaria touched upon nothing less than the very perception of postwar Bavarian identity. Ever since 1945, the state of Bavaria had adhered to the designation Freistaat, a term that, like Volksstaat, also denoted a republican form of government. For the SPD, of course, establishing Eisner as the founder of the Freistaat legitimated their own historic claims to having shaped the state's identity and enhanced the party's political prestige. Yet, in a state solidly ruled since the end of World War II by the conservative CSU, any linkage of its current political identity to an unpopular independent socialist figure such as Eisner was bound to threaten the party's own claims to power and thus would be unwelcome. ${ }^{66}$ Determining the exact nature of Eisner's historical role in creating the Bavarian republic thus was an issue of strategic importance.

Ultimately, the resolution of the monument's text was settled not by historical fact but by a politically-colored interpretation of history. As SPD member Alfred Lottmann insisted in an emotional city council debate in February 1989, the fact that Eisner proclaimed Bavaria to be a Freistaat already in his first addresss to the Landtag on 7 November 1918 firmly established him as the founder of the state's current designation. Eisner, he argued, viewed the term as denoting independence from monarchy; the term Volksstaat for him merely denoted the fact that all "state authority emanated from the people" and simply signified "a democratic

64. RMDSS/RP, Bauausschuss, 2 February 1989, Aktensammlung, 506.

65. RMDSS/RP, Stadtrat, 22 February 1989, 113-44.

66. In addition to having dominated the post of Minister President (except during the tenure of Wilhelm Hoegner), The CSU has possessed an absolute majority in the Landtag since 1962. Rainer A. Roth, Freistaat Bayern: Politische Landeskunde (Munich, 1994), 73. 
system of government distinct from dictatorship." CSU representatives responded by citing a range of primary sources from the era to show that, while Eisner may well have first used the term Freistaat, his regime quickly adopted the term Volksstaat instead; the term Freistaat, they argued, entered into standard usage only after May 1919 when the cabinet of Johannes Hoffmann adopted it to separate itself from the bygone revolutionary regimes. ${ }^{67}$ Yet, CSU councilman Zehetmaier's conclusion that "one can hardly assert any identity between the republic that Eisner proclaimed and our Freistaat created after the war," elicited sharp responses from SPD representatives. As SPD councilman Klaus Junger argued, the distinguishing elements of Eisner's republic were all to be found in the current Bavarian system: the republican system of government (marking the liberation from the "rotten monarchy"), universal suffrage, democratic elections, and a federalistic orientation. The modern Freistaat of Bavaria, though certainly different from the Freistaat proclaimed by Eisner, had its origins within it. Ultimately, however, SPD mayor Georg Kronawitter's remark that the choice of Freistaat or Volksstaat would be a "political decision" was borne out by events. In the final city council vote, the CSU was victorious. When at last dedicated later in the year, the new text of the monument read: "Kurt Eisner, who proclaimed the Bavarian Republik on 9 November 1918, and the future prime minister of the Volksstaat of Bavaria was murdered on this spot on February 21, 1919." In denying Eisner any links to the term Freistaat, the conservative CSU maintained its protectionist claims upon it. ${ }^{68}$

Although the politicized decision to deny Eisner's contribution to the modern Bavarian state indicated continuing discomfort with his legacy, the resulting monument nevertheless represented the dramatic evolution of his place in postwar memory. A historical legacy that had once been marginalized silently from the cityscape had now acquired a central place within it. An additional indication of the revision of memory in the 1980s was provided by a second alteration to the Revolutionsdenkmal in the Ostfriedhof in 1989. While the cubic stone monument, destroyed by the Nazis, had been restored in 1958 , it had only regained one undescriptive text, "To the dead of the revolution of 1919." In 1989, however, local labor unions marked the 70th anniversary of the crushing of the Räterepublik by once more engraving the stone with its original quotation by Ernst Toller, as well as two new phrases: "In memory of Kurt Eisner, 18671918" and, more notably, "To the Victims of the Resistance, 1933-1945." Once again, in linking the victims of the "white" troops and those of 
their more politically extreme descendents, the Nazis, this last textual addition offered an implicit message about historical causality. For the Left, the revolutions of 1918-1919 remained important as a means of illuminating the larger lessons of the Third Reich. In commemorating the persecution of the Left by the Right in two different historical eras, the monument served, according to union leader Jakob Deffner, the intended function of urging resistance to "racism, fascism, and [support] for freedom and democracy." ${ }^{69}$ In effect, the alteration of the Revolutionsdenkmal provided the Left with a site to express its own view of the past denied to it in front of the Palais Montgelas. The very need to acquire such commemorative parity, however, attested to the continuing inability to arrive at a mnemonic consensus. ${ }^{70}$

Finally, as demonstrated by the range of fleeting controversies occasioned by the 75th anniversary of the Bavarian revolutions in 1993-94, the politicization of memory has continued. The CSU provided further indications of its continuing historical amnesia by the refusal of party leaders such as German Finance Minister Theo Waigel and Bavarian Minister President Edmund Stoiber in November 1993 to attend an SPD-sponsored ceremony in the Munich Residenz marking the 75th anniversary of Eisner's proclamation of the Bavarian republic. Claiming that he was "unable to associate the birthdate of democratic ... Bavaria with the proclamation of the Soviet Republic by Kurt Eisner," Waigel excused himself by a careless, yet politically shrewd, misuse of history typical of local postwar conservatives. ${ }^{71}$ And yet, in contrast to this display of "ignorance," signs of the expansion of local collective memory have continued to appear in Munich, as demonstrated by the provisional erection of an unsolicited commemorative plaque in honor of Gustav Landauer at Munich's Stadelheim prison in late April 1994. Although quickly removed by local authorities, the plaque's blunt text- "Gustav Landauer was murdered here on May 2, 1919 "- and the theatrical spilling of tomato juice in front of it by its creators demonstrated a new willingness to confront uncommemorated aspects of the city's revolutionary past. ${ }^{72}$ Importantly, this impulse received official state sanction in late January 1997, when Munich Mayor Christian Ude unveiled a permanent plaque to Gustav Landauer in Schwabing with the intent of "rescuing Landauer from oblivion" and acknowledging

69. "Die Inschrift und das Vermächtnis aufpoliert," $S Z, 23$ May 1989, p. 15.

70. The naming of "Erich-Mühsam-Platz" in Schwabing in 1989 also represents the creation of a site for the political Left. Dollinger, Die Münchner Strassennamen, 72.

71. Christian Schneider, "Historikerstreit auf bayerisch," SZ, 6/7 November 1993, p. 3.

72. "Mit Verkehrsschild und Tomatensaft," $S Z, 25$ April 1994, p. 14; "Denken an einen Ermordeten," Abendzeitung, 25 April 1994, p. 12. The monument was erected by the local artists Wolfram Kastner and Eckhard Zylla. 
his historic importance as an intellectual and politician. ${ }^{73}$ After more than 75 years, the revolutions of 1918-1919 continued to spark dissension as well as further acts of commemoration.

In conclusion, the wide range of commemorative acts undertaken on behalf of Kurt Eisner and the Bavarian revolutions of 1918-1919 in postwar Munich demonstrates both the dynamism and ambiguity of local collective memory. On the one hand, a dynamic pattern of increasing openness toward the revolutionary past over time clearly emerges from a survey of the city's monuments. The first responses toward the events of 19181919 in post-1945 Munich were limited to eliminating the Nazi regime's view of the past through the demolition of its monuments. The next attempts to commemorate Eisner sought merely to restore older, Weimarera monuments to him; this modest goal, however, was still too radical for the late 1940s and only was successful in the late 1950s. Gradually, however, more proactive measures were taken. To be sure, the act of creating a mere street name after Eisner in an outlying suburb in 1969 was a fairly tentative one; given the popular opposition to it, however, this modest move may well have been all that could have been expected at the time. The fact that the next commemoration in 1973 took the form of a tangible plaque located in the city center rather than a mere street name in the suburbs represented yet another advance; however, its relegation to an obscure site made it fall short of realizing its commemorative potential. Finally, the last monument erected in Eisner's memory in 1989 surpassed all previous ones in its combination of figurative and textual form as well as its prominent location; yet, it too was marked by some degree of historical reticence. As indicated by this increasingly explicit trajectory of commemoration, the position of the revolutionary past in local memory has experienced an undeniable, if halting, expansion. Its increasingly prominent physical "place" in the city reflects its evolution in local collective memory.

And yet, local memory in Munich has stubbornly resisted the imposition of consensus. This absence has resulted largely from the tendency of both the Left and the Right to tailor their views of the past to serve their own very different political ends. In the process, both have viewed the past selectively; the Right has refused to de-demonize Eisner or acknowledge his historic accomplishments, while the Left has covered up its Weimar-

73. "Eine Tafel erinnert jetzt an Gustav Landauer," $S Z, 25 / 26$ January 1997, p. 45. The plaque's text reads: "Gustav Landauer, 1870-1919, philosopher, translator, and briefly, People's Representative for Popular Enlightenment, was murdered at the end of the Munich Soviet Republic on May 2, 1919 in Munich-Stadelheim, as a radical socialist and violent anarchist." 
era hostility to him with an opportunistic and hagiographic postwar position. The primary distortions of the past's facticity, however, seem to have been caused more by the Right than the Left. That Kurt Eisner today is still denied credit for founding the Bavarian Freistaat and is still viewed by some as responsible for the Räterepublik attests not only to deficiencies in memory but to the continuing instrumentalization of it for political gain. This persistence of distortion certainly indicates the limited educational power of monuments; although the many monuments erected in postwar Munich have helped erode historic prejudices, they have not succeeded in eradicating them entirely. ${ }^{74}$. And to some degree, this is a matter of concern. For the absence of a balanced view of the past, after all, obstructs a full understanding of the present.

Nevertheless, certain virtues may be found in the continuing absence of mnemonic consensus. In part, it is precisely because Munich's revolutionary past constantly has provoked politicized disagreement and resisted consensus that it has continued to occupy any place at all, let alone an important one, in local collective memory. ${ }^{75}$ As demonstrated by the perpetual battle between the Left and the Right over the past's legacy, it seems clear that the past is not so much remembered for its own sake as for utilitarian purposes-especially political gain. Conversely, the less the past is mobilized to serve a particular political end, the sooner it seems to be condemned to fade from neglect. In light of Michael Kammen's remark that "memory is... activated by contestation... [while] amnesia is ... induced by the desire for reconciliation," it appears that preserving memory is guaranteed less by fostering agreement about the definitive "truth" about the past, than by the continual clash of competing views of it. ${ }^{76}$ Only by tolerating and contesting the distortion of the past, paradoxically, can the active memory of it be promoted.

Finally, the continuing struggles with the legacy of the revolutions of 1918-1919 in postwar Munich reveal that local collective memory has remained preoccupied with weighty issues beyond the insurmountable legacy of the Third Reich. Although "coming to terms with" the past has, since 1945, referred to the Nazi era, it appears that there are, indeed, multiple

74. To a degree, this failure reflects a built-in deficiency of monuments which, as many observers have pointed out, do not preserve memory to the extent commonly assumed. Whether or not one fully accepts the somewhat cynical views of Robert Musil that "there is nothing in the world so invisible as [a] monument" or James Young, that "the more memory comes to rest in its exteriorized forms, the less it is experienced internally," one must avoid the naive assumption that monuments inevitably preserve memory. Robert Musil, Gesammelte Werke (Reinbek bei Hamburg, 1978), 506; Young, The Texture of Memory, 5.

75. James Young has addressed this issue in noting that "the surest engagement with memory lies in its perpetual irresolution." Young, The Texture of Memory, 21.

76. Michael Kammen, Mystic Chords of Memory: The Transformation of Tradition in American Culture (New York, 1991), 13. 
"pasts" that still need to be "worked through." And yet, the memory of Kurt Eisner and the Bavarian revolutions has not fully been able to escape the shadows of the historical events that followed thereafter. Indeed, the memory of the era of 1918-1919 has been substantially refracted through local views of the Nazi past. If only to a limited degree, conservatives have linked the two periods in seeing Eisner's revolutionary recklessness as partially responsible for the rise of the Nazis. Much more frequently, liberals and those on the political Left have also represented the two periods as connected; yet while they have likewise seen the rise of the Nazis as rooted in the revolutionary events of 1918-1919, they have argued clearly that it was due to the Right's violent intolerance and eventual crushing of the Left that propelled the Nazis to prominence. In both cases, it is clear that the place of Kurt Eisner and the Bavarian revolutions in local memory has not been an uncontested one.

These two insights, finally, may shed light upon the likely direction in which the working through of the East German past-the second Vergangenheitsbewältigung - will proceed. As shown by postwar Munich's relationship to its own left-wing revolutionary legacy, and in light of the fundamental importance of anticommunism for the postwar identity of the Federal Republic, it is probable that the integration of the left-wing, East German identity into that of reunified Germany will be a painfully incremental process. Of course, after having attempted to "master" the Nazi past for over fifty years, the Germans have developed a sophisticated understanding of the workings of memory; the discussions about the legacy of the former GDR, therefore, will not likely suffer the same delays getting started, as was the case with the Nazi past. The confrontation with the East German past is still in its infancy, however. As the recent controversial demolition of many East German monuments demonstrates, the unified Federal Republic of Germany has only arrived at the point where its leaders have been confident enough to cast aside the historical views of the bygone communist regime. ${ }^{77}$ If the insights provided by the treatment of Kurt Eisner in postwar Munich are any indication, however, the erection of new monuments commemorating various aspects of the East German past (whether to older communist heroes honored in the GDR, such as Rosa Luxemburg or Ernst Thälmann, or fallen would-be reformers such as Rudolf Herrnstadt) will take longer to realize. These and

77. For a wide range of essays concerning the toppling of GDR monuments in the early 1990s, see the entire issue of kritische berichte 3 (entitled "Der Fall der Denkmäler) (1992). See also Martin Schönfeld, "Erhalten-Zerstören-Verändern? Diskussionsprozesse um die politischen Denkmäler der DDR in Berlin," kritische berichte 1 (1991): 39-43 and Hubertus Adam, "Zwischen Anspruch und Wirkungslosigkeit: Bemerkungen zur Rezeption von Denkmälern der DDR," kritische berichte 1 (1991): 44-64. 
other such future commemorations promise to be divisive and politicized. Beyond the issue of politicization, the case of Kurt Eisner further suggests that the memory of the East German past also will be refracted through the memory of the Third Reich. As demonstrated by the resurgence in scholarly interest in the concept of totalitarianism, the dictatorship of the proletariat probably will continue to be compared to the dictatorship of the Führer. ${ }^{78}$ The East German past will remain in the foreground for the foreseeable future; but in the background will lurk the Nazi past, as it has since 1945. For these reasons, the second Vergangenheitsbewältigung is better understood as a double Vergangenheitsbewältigung. Without any doubt, the past will continue to occupy the present concerns of Germans for a long time to come.

\section{UNIVERSITY OF CALIFORNIA AT LOS ANGELES}

